\title{
Screening of Bhendi Accessions (Abelmoschus esculenthus [L.] Moench) against the Fruit Borer, Earias spp. (Noctuidae; Lepidoptera)
}

\section{Chandrasekaran}

Department of Plant Protection, Horticultural College and Research Institute for women, Tamil Nadu Agricultural University, Tiruchirappalli - 620 027, Tamil Nadu, India

"Corresponding author: chantrue2020@gmail.com (ORCID ID: 0000-0001-8414-9539)

Paper No. 832

Received: $22-12-2019$

Revised: 17-04-2020

Accepted: 20-05-2020

\begin{abstract}
The study on screening of bhendi accessions against fruit borer (Earias spp.) infestation was conducted by evaluating 55 numbers of IC entries with 6 different varieties/hybrids as a local standard check to assess their performance in naturally infested field conditions in augmented block design with three replications. The identified resources of accessions further subjected to the artificial screening to cross verify their reaction against the incidence of sucking insect pests, viz., leaf hopper (Amrasca biguttula biguttula) and whitefly (Bemisia tabaci). Out of 55 IC accessions screened, the entries viz., IC 27821-A, IC 42531, IC 22237-C, IC 42485-B, IC 43743, IC 43746-D, IC 45728 and IC 45804 were found to be the best tolerant sources for the management of fruit borer, Earias spp. with the cross resistance to leaf hopper and whitefly. The results on the artificial screening indicated that the identified tolerant sources were registered the minimum leaf hopper index $(<3.5)$ and whitefly population $(<2.0 /$ leaf $)$ when compared with the susceptible checks like Arka anamika, Parbhani kranti, Punjab 8 and Punjab padmini. The tolerance nature of the identified entries by recording $<30$ per cent fruit damage with the trichome density of $>$ $80 / \mathrm{cm}^{2}$ is in tune with the tolerant checks i.e., CO 4 and Arka abhay. Hence, the present investigation conclude that, these identified 8 accessions can be utilized in further breeding programmes to develop varieties/hybrids resistant to major insect pests of bhendi with good phenological traits.

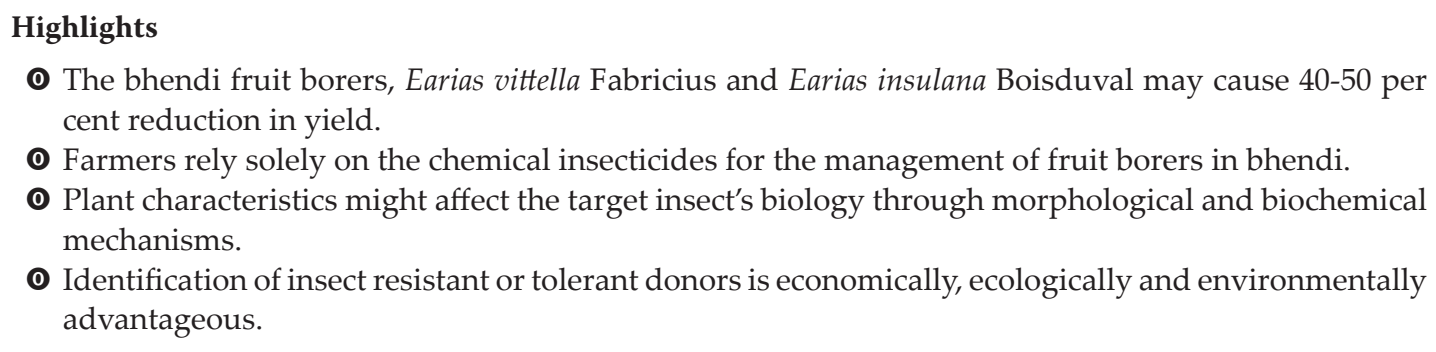

Keywords: Bhendi, accessions, fruit borer, Earias spp., leaf hopper and whitefly

Bhendi is predominantly a crop of tropics and subtropics in India, bhendi, Abelmoschus esculentus (L.) Moench is cultivated in almost all the states and its largest producers are Bihar, Orissa, West Bengal, Assam, Andhra Pradesh, Tamil Nadu and Karnataka. It occupies fifth position, next to tomato, in area under vegetables in the country with a production of 33.24 lakh metric tonnes from an area of 3.47 lakh hectares. The crop is cultivated for its young tender fruits, used in curry and soups after cooking. It is a good source of vitamins A and $\mathrm{B}$, protein and minerals. It is also an excellent source of iodine and is useful for the treatment of goiter. Fruit is useful against genitor-urinary 
disorders, spermetorrhoea and chronic dysentery. Bhendi is ravaged by many insect pests right from germination of seeds to harvest of fruits. The fruit borers, Earias vittella Fabricius and Earias insulana Boisduval cause extensive damage to fruits, results in 40-50 per cent reduction in yield (Sumathi, 1999). Farmers rely solely on the chemical insecticides for the management of pests of bhendi because of easy adaptability, immediate and spectacular knockdown effects of pesticides on insects (Pawar et al. 1988; Verma 1989). Despite these credentials, continuous use of chemical insecticides has been found to be ecologically unsafe and indiscriminate use of insecticides has resulted in development of resistance by insects to insecticides, resurgence of primary pests, upsurgence of secondary pests, inimical to predators and parasitoids, accumulation of pesticides residues in fruits (Mitra et al. 1999), break-down of food web in natural ecosystem and environmental pollution (Mahapatro and Gupta 1998). The basic concept of Integrated Pest Management (IPM) is to make need based use of pesticides instead of indiscriminate use of chemicals (Mahapatro 1999). Identification of wild and cultivated okra donors for fruit borer resistance and development of resistant varieties (Prabhu 2009), bio-rational pesticides encompassing the botanicals and microbials as ideal components of IPM (Singh 1996; Ramarethinam 1998; Kumbhar et al. 2000). Realizing the importance, the present investigation was undertaken on the screening of bhendi accessions (Abelmoschus esculenthus [L.] Moench) to identify the source of resistance/tolerance against the fruit borer, Earias spp. (Noctuidae; Lepidoptera).

\section{MATERIALS AND METHODS}

The present investigation was carried out in Department of Plant protection, Horticultural College and Research Institute for women, Tamil Nadu Agricultural University, Tiruchirappalli District of Tamil Nadu during the year 2017 - 20 . The experimental garden land is located in mid zone of Tamil Nadu state at $10^{\circ} 45^{\prime} \mathrm{N}$ latitude and $78^{\circ} 36^{\prime} \mathrm{E}$ longitude at an altitude of 85 meters above the mean sea level. The bhendi seed materials used for screening against the fruit borer, Earias spp., are comprised of 55 accessions with the 6 numbers of ruled varieties/hybrids, as standard check for location specific comparison. The experiment was laid out in augmented block design with three replications. Each treatment in each replication was represented by 5 meters row with 20 plants at spacing of $60 \times 30 \mathrm{~cm}$. The list of bhendi entries with its accession number was given in Table 1 . During the cropping period no spraying was done for the management of any insect pests that infesting the crop. However, all the regular agronomic practices were adapted as per the recommendations. To access the fruit borer damage, the observation parameters viz., plant height, fruit length, fruit girth and fruit damage were recorded. The plant height in each entry was recorded from five plants tagged at random per replication at 10 days interval up to the last harvest and the average plant height $(\mathrm{cm})$ of individual entry was worked out. The length and girth were recorded at each harvest from five tagged plants in each replication and the mean fruit length $(\mathrm{cm})$ and girth $(\mathrm{cm})$ of individual entries were worked out. The fruits were observed at each harvest, the fruit borer infestation is computed by counting the total and affected number of fruits from five plants per row at random and per cent damage was worked out by using the formulae.

Fruit borer incidence $=\frac{\text { Number of fruits infested }}{\text { Total Number of fruits }} \times 100$

Based on the mean per cent damage of ten harvests the entries were classified in to 1-6 grade as suggested by Rai and Satpathy (1998).

Table 1: Scale for fruit borer resistance (based on per cent infestation)

\begin{tabular}{lll}
\hline Scale & $\begin{array}{l}\text { Percentage Infestation } \\
\text { of fruits }\end{array}$ & Rating Category \\
\hline 1 & 0 & Immune (I) \\
2 & $0.1-10 \%$ & Highly Resistant (HR) \\
3 & $10.1-20 \%$ & Fairly Resistant (FR) \\
4 & $20.1-30 \%$ & Tolerant (T) \\
5 & $30.1-40 \%$ & Susceptible (S) \\
6 & 40.1 and above & Highly Susceptible (HS) \\
\hline
\end{tabular}

The artificial screening of identified fruit borer resistant entries was carried out to assess and cross verify their reaction against the incidence of sucking insect pests, viz., jassid (Amrasca biguttula biguttula) and whitefly (Bemisia tabaci). The observation for mean jassid (nymph) and whitefly (adult) population per leaf was counted in the morning 
hours at fortnight interval from the five tagged plants of each accessions stating from $15^{\text {th }}$ day after sowing to 100 days of sowing by taking 5 leaves per plant i.e., two each from top and middle and one from bottom at random. The leaf hopper injury index (Table 2) was calculated according to Bindra and Mahal (1979), which is as follows.

Table 2: Leaf Hopper Injury Grade for screening bhendi accessions

\begin{tabular}{|c|c|c|}
\hline Grade & Nature of Damage & Level of injury \\
\hline 1 & No damage & Entire leaf green \\
\hline 2 & Low damage & $\begin{array}{l}\text { About } 25 \% \text { leaf area showing } \\
\text { hopper burn, yellowing at } \\
\text { margin }\end{array}$ \\
\hline 3 & Medium damage & $\begin{array}{l}\text { About } 50 \% \text { leaf area showing } \\
\text { hopper burn, slightly cupping } \\
\text { at margin }\end{array}$ \\
\hline 4 & High damage & $\begin{array}{l}\text { About } 75 \% \text { leaf area showing } \\
\text { hopper burn, severe cupping } \\
\text { and bronzing }\end{array}$ \\
\hline 5 & Severe damage & $\begin{array}{l}\text { Entire leaf tissue showing } \\
\text { hopper burn and becoming } \\
\text { dead }\end{array}$ \\
\hline
\end{tabular}

Leaf hopper Injury Index for identified accessions were worked out by following the formula:

Leaf hopper Injury Index =

$$
\frac{G_{1} L_{a}+G_{2} L_{b}+G_{3} L_{c}+G_{4} L_{d}+G_{5} L_{e}}{L_{a}+L_{b}+L_{c}+L_{d}+L_{e}}
$$

Where $\mathrm{L}_{\mathrm{a}}$ to $\mathrm{L}_{\mathrm{e}}$ is number of leaves falling under leaf hopper injury grades $G_{1}$ to $G_{5}$, respectively.

\section{RESULTS AND DISCUSSION}

The pooled results of the observation parameters recorded during the three consecutive experimental seasons showed that, the bhendi entries viz., IC 27821-A, IC 42531, IC 22237-C, IC 42485-B, IC 43743, IC 43746-D, IC 45728 and IC 45804 were registered < 30 per cent fruit borer damage with the fruit length $(15.08-16.75 \mathrm{~cm})$ and girth $(5.10-6.42 \mathrm{~cm})$ and identified as the tolerant sources against the fruit borer, Earias sp. and when compare with the check varieties, CO 4 and Arka abhay which recorded the minimum per cent fruit damage of 23.49 and 28.33 with the fruit length $(16.88 \& 15.46 \mathrm{~cm})$ and girth $(5.86 \& 5.15 \mathrm{~cm})$. Among the entries which identified as tolerant sources, The minimum fruit damage i.e., $<25 \%$ with the average good fruit length of 16.30 and 16.60 and the fruit girth of 5.51 and 5.81 scored by the entries IC 27821-A and IC 42485-B, respectively and identified as the best tolerant accessions against the incidence of bhendi fruit borer, Earias sp.. It was followed by the accessions IC 18960-C and IC 29136 by registering the per cent fruit damage of 30.72 and 31.26, which are very nearer to the tolerant entries which identified. The entries viz., IC 22232, IC 24909-A, IC 27878, IC 29136, IC 29359, IC 31850-A, IC 42524, IC 43722, IC 45817, IC 45895, IC 45955, IC 45992-B, IC 03769-A, IC 04328, IC 12933, IC 12994, IC 18960-C and IC 29119-B were found under the scoring category of susceptible and the performance of these entries were in tune with the check varieties viz., Arka anamika, Punjab Padmini, Punjab 8 and Prabhani Kranti with the per cent Earias sp. fruit damage of 30.10 - 40.00 (Table 3).

The entries identified as tolerance sources against the fruit borer, Earias spp. was also registered the maximum trichome density $\left(>80 / \mathrm{cm}^{2}\right)$. The fruits of identified accessions have more number of trichomes on surface and the fruit was also tough, which renders the tolerance against Earias spp. infestation. The present investigation on the influence of fruit laminal hairiness in reducing the fruit damage is also conferred by the previous reports of Nerkar (1990) and Prabhu (2009). The previous workers, Hooda et al. (1997); Sharma and Singh (2010); Anitha and Karthika (2018) also reported a significant negative correlation between trichome density and borer infestation in okra. The presence of inbuilt inheritance characteristics of resistance, tolerance and immunity level against fruit borer infestation in many Abelmoschus spp. was also reported in the annual report of PDVR (1994). The artificial screening of identified entries was carried out and the observations are given in Table 4. The observations indicated that these entries registered the maximum trichome density of $79.00-$ $89.40 / \mathrm{cm}^{2}$ with the minimum fruit borer damage $(<$ $30 \%$ ). The reaction of these identified entries against sucking insect pests viz., leaf hopper and whitefly showed that the minimum leaf hopper index of 1.40 was registered in the entry IC 42531 with the whitefly population of $0.80 /$ leaf. The leaf hopper population was $<3$ per leaf and the white fly population of 1.20 and 1.40/leaf, respectively in the entries IC 27821 - A and IC 22237-C. It was also observed that 
Table 3: Screening of entries /accessions against the bhendi fruit borer, Earias sp. (2017-20)

\begin{tabular}{|c|c|c|c|c|c|c|}
\hline \multirow[b]{2}{*}{ Sl. No. } & \multirow[b]{2}{*}{ Entries/Accessions } & \multicolumn{4}{|c|}{ Mean of three consecutive seasons (2017-20) } & \multirow[b]{2}{*}{ Rating } \\
\hline & & $\begin{array}{l}\text { Plant Height } \\
\text { (in cm) }\end{array}$ & $\begin{array}{l}\text { Fruit Length } \\
\text { (in cm) }\end{array}$ & $\begin{array}{l}\text { Fruit Girth } \\
(\text { in } \mathrm{cm})\end{array}$ & $\begin{array}{l}\text { Fruit damage } \\
(\%)\end{array}$ & \\
\hline 1 & IC 18973-A & 63.95 & 14.58 & 5.59 & 49.62 & HS \\
\hline 3 & IC 22232 & 57.86 & 17.05 & 6.30 & 34.38 & $S$ \\
\hline 4 & IC 24903-A & 65.82 & 14.94 & 5.40 & 42.54 & HS \\
\hline 7 & IC 26375 & 71.15 & 14.87 & 5.21 & 44.84 & HS \\
\hline 8 & IC 27821-A & 58.50 & 16.30 & 5.51 & 23.50 & $\mathrm{~T}$ \\
\hline 9 & IC 27826-A & 60.69 & 12.50 & 5.99 & 43.98 & HS \\
\hline 10 & IC 27877 & 59.35 & 14.72 & 5.46 & 49.33 & HS \\
\hline 11 & IC 27878 & 74.11 & 16.00 & 5.65 & 39.94 & $S$ \\
\hline 15 & IC 31398-B & 62.79 & 12.84 & 5.92 & 45.51 & HS \\
\hline 16 & IC 31850 & 63.00 & 13.99 & 5.37 & 55.61 & HS \\
\hline 17 & IC 31850-A & 61.95 & 16.31 & 6.07 & 33.19 & $S$ \\
\hline 18 & IC42524 & 73.05 & 15.48 & 5.36 & 39.25 & S \\
\hline 19 & IC 42531 & 66.74 & 16.88 & 5.79 & 25.97 & $\mathrm{~T}$ \\
\hline 20 & IC 43587 & 67.79 & 13.88 & 5.89 & 46.28 & HS \\
\hline 21 & IC 43722 & 69.11 & 15.31 & 5.80 & 39.14 & $S$ \\
\hline 22 & IC 45815 & 71.29 & 14.20 & 5.55 & 43.88 & HS \\
\hline 23 & IC 45817 & 69.47 & 15.26 & 6.04 & 37.06 & $S$ \\
\hline 24 & IC 45895 & 67.00 & 15.13 & 5.67 & 37.22 & $S$ \\
\hline 31 & IC 03769 & 65.39 & 17.81 & 5.99 & 44.84 & HS \\
\hline 32 & IC 03769-A & 64.44 & 16.78 & 6.24 & 37.38 & S \\
\hline 33 & IC 04284-A & 69.28 & 14.17 & 6.15 & 45.37 & HS \\
\hline 34 & IC 04328 & 63.67 & 16.22 & 5.93 & 39.27 & $S$ \\
\hline 35 & IC 10256-B & 56.96 & 14.62 & 5.78 & 44.93 & HS \\
\hline 36 & IC 10265 & 64.61 & 17.32 & 5.85 & 42.56 & HS \\
\hline 37 & IC 10533 & 77.63 & 12.69 & 6.08 & 46.48 & HS \\
\hline 38 & IC 12933 & 67.49 & 16.29 & 6.20 & 34.60 & $S$ \\
\hline 39 & IC 12994 & 87.07 & 14.20 & 6.27 & 38.65 & S \\
\hline 40 & IC 18960-C & 69.52 & 16.03 & 6.07 & 30.72 & $S$ \\
\hline 41 & IC 22237-C & 82.36 & 16.70 & 6.27 & 28.09 & $\mathrm{~T}$ \\
\hline 42 & IC29119-B & 81.02 & 17.37 & 5.81 & 37.22 & $S$ \\
\hline 43 & IC 29168-A & 55.83 & 12.59 & 5.89 & 42.34 & HS \\
\hline 44 & IC 29359-B & 58.75 & 14.97 & 5.11 & 48.32 & HS \\
\hline 45 & IC 42485-B & 62.63 & 16.60 & 5.81 & 23.00 & $\mathrm{~T}$ \\
\hline 46 & IC42490 & 75.81 & 13.47 & 6.09 & 49.28 & HS \\
\hline 47 & IC 42490-A & 60.50 & 13.19 & 5.73 & 49.47 & HS \\
\hline 48 & IC 43743 & 59.37 & 16.24 & 5.88 & 26.85 & $\mathrm{~T}$ \\
\hline 49 & IC 43746-D & 68.16 & 17.00 & 6.16 & 26.35 & $\mathrm{~T}$ \\
\hline 50 & IC 45728 & 72.04 & 16.33 & 5.59 & 26.39 & $\mathrm{~T}$ \\
\hline
\end{tabular}




\begin{tabular}{|c|c|c|c|c|c|c|}
\hline 51 & IC 45730 & 68.61 & 16.57 & 5.36 & 43.06 & HS \\
\hline 52 & IC 45804 & 67.81 & 15.90 & 5.82 & 28.07 & $\mathrm{~T}$ \\
\hline 53 & IC45813 & 57.49 & 13.59 & 5.37 & 46.57 & HS \\
\hline 54 & IC 45814 & 66.62 & 14.44 & 5.68 & 48.73 & HS \\
\hline 55 & IC 45821 & 78.03 & 14.65 & 5.49 & 46.97 & HS \\
\hline 56 & $\mathrm{CO} 4$ & 82.48 & 16.88 & 5.86 & 23.49 & $\mathrm{~T}$ \\
\hline 57 & Arka anamika & 69.38 & 14.92 & 5.71 & 35.50 & $S$ \\
\hline 58 & Arka abhay & 69.92 & 15.46 & 5.15 & 28.33 & $\mathrm{~T}$ \\
\hline 59 & Punjab Padmini & 70.48 & 15.04 & 5.95 & 35.38 & $\mathrm{~S}$ \\
\hline 60 & Prabhani Kranti & 72.16 & 15.24 & 5.95 & 36.90 & $S$ \\
\hline 61 & Punjab 8 & 63.53 & 15.31 & 5.58 & 35.35 & $\mathrm{~S}$ \\
\hline
\end{tabular}

Table 4: Reaction of identified entries/accessions against the major insect pests of bhendi

\begin{tabular}{llllllll}
\hline S1. No. & Entries & $\begin{array}{l}\text { Leaf hopper } \\
\text { (Nymph) } \\
\text { Population/leaf }\end{array}$ & $\begin{array}{l}\text { Leaf } \\
\text { hopper } \\
\text { Index }\end{array}$ & $\begin{array}{l}\text { Whitefly } \\
\text { Population/ } \\
\text { leaf }\end{array}$ & $\begin{array}{l}\text { Trichome } \\
\text { Density/cm }{ }^{2}\end{array}$ & $\begin{array}{l}\text { Fruit } \\
\text { Damage } \\
\text { (\%) }\end{array}$ & Rating \\
\hline 1 & IC 27821-A & 2.62 & 2.43 & 1.20 & 89.40 & 24.86 & $\mathrm{~T}$ \\
2 & IC 42531 & 1.92 & 1.40 & 0.80 & 88.72 & 24.90 & $\mathrm{~T}$ \\
3 & IC 22237-C & 2.26 & 2.19 & 1.40 & 79.52 & 26.48 & $\mathrm{~T}$ \\
4 & IC 42485-B & 3.66 & 3.40 & 1.80 & 86.44 & 25.64 & $\mathrm{~T}$ \\
5 & IC 43743 & 3.76 & 3.28 & 1.20 & 82.41 & 26.68 & $\mathrm{~T}$ \\
6 & IC 43746-D & 3.76 & 3.32 & 1.40 & 86.20 & 25.56 & $\mathrm{~T}$ \\
7 & IC 45728 & 3.74 & 3.46 & 1.20 & 80.82 & 26.94 & $\mathrm{~T}$ \\
8 & IC 45804 & 3.62 & 3.40 & 1.80 & 86.22 & 25.90 & $\mathrm{~T}$ \\
9 & Co 4 & 2.60 & 2.74 & 0.40 & 88.84 & 23.48 & $\mathrm{~T}$ \\
10 & Arka abhay & 2.64 & 2.46 & 1.40 & 86.46 & 27.64 & $\mathrm{~T}$ \\
11 & Arka anamika & 3.82 & 3.62 & 2.00 & 68.60 & 34.22 & $\mathrm{~S}$ \\
\hline
\end{tabular}

the leafhopper Injury Index was increased with the increase in nymph leaf hopper population per leaf. The lower leaf hopper population registered in the identified entries might be due to its maximum number of trichomes as reported by Nerkar (1990) and Dhankar (1998) that increased laminal hairiness having the negative relation with the leaf hopper population. Considering the incidence of whitefly all the reaction of identified accessions is found to be good by scoring $<2$ numbers per leaf with negligible symptoms of Yellow vein Mosaic Virus (YVMV) symptom expression. The positive correlation recorded on whitefly population with the incidence of YVMV is in tune with the findings of Board et al. (1993) and Pun et.al. (2005).

\section{CONCLUSION}

Bhendi is a most important vegetable crop in almost all the states of India. There are about 13 major insect and non-insect pests which attack at different stages of its growth. Among them, the shoot and fruit borer, Earias spp. is the main bottleneck for the cultivation of bhendi crop. The negative impacts created by the indiscriminate usage of the insecticides for the management of fruit borer and other sucking insect pests had stimulate the researchers to find out some alternative methods, of which the identification and utilization of resistant or tolerant donors is the ideal one. Since there is no stable source of resistance, the promising accessions identified in the present investigation can be further exploited by breeding programmes to develop durable varieties against the major insect pests of bhendi for the benefit of farming community.

\section{ACKNOWLEDGEMENTS}

I am greatly thankful to the Director, Centre for Plant Protection Studies, the Director of Research and the Dean, Horticultural College and Research Institute for women, Tamil Nadu Agricultural University, for their continuous support and providing facilities for conducting the field and lab experiments. 


\section{REFERENCES}

Anitha, S. and Karthika, N. 2018. Antixenosis resistance in okra accessions against shoot and fruit borer, Earias vittella (FAB.). Journal of Phytology, 10: 27-32.

Bindra, O.S. and Mahal, M.S. 1979. Investigation on varietal resistance in okra, Abelmoschus esculentus (L.) Moench to the cotton jassid. Amrasca biguttula biguttula. Ind. J of Horticulture, 36: 212-219.

Borad, V.K., Puri, S.N., Brown, J.K. and Butler, G.D. 1993. Relationship of Bemisia tabaci population density and yellow vein mosaic disease incidence in okra. Pest Management and Economic Zoology, 1: 14-15.

Dhankar, B.S. 1998. Recent advances in okra breeding. Instructional manual of summer school on "Advanced technologies in improvement of vegetable crops including cole crops". May 4-24, AIRI, New Delhi, India, pp. 196-199.

Hooda, V.S., Dhankar, B.S. and Singh, R. 1997. Evaluaion of okra cultivars for field resistance to the leaf hopper, Amrasca bigittula bigittula (Ishida). Insect science and application, 17: 323-327.

Kumbhar, P.P., Salunkhe, D.H., Borse, M.B., Hiwale, M.S., Nikam, L.B., Bendre, R.S., Kulkarni, M.V. and Dewang, P.M. 2000. Pestidal potency of some common plant extract. Pestology, 24(6): 51-53.

Mahapatro, G.K. and Gupta, G.P. 1998. Pesticide induced resurgence. Pestology, 22(12): 14-16.

Mahapatro, G.K. 1999. Pesticides: Boon or Bane? Discussing its changed role in integrated pest management. Pestology, 23(6): 31-36.

Mitra, N. G., Upadhya, A., Sachidanand B. and Agarwal, G.D. 1999. Contamination of pesticides in samples of milk and milk products. Pestology, 28(8): 36-40.

Nerkar, Y.S. 1990. The use of related species in transferring disease and pest resistance genes to okra. Report of an International workshop on okra genetic resources held at the NBPGR. New Delhi, India, 8-12 ${ }^{\text {th }}$ October, pp. 110-112.
Pawar, D.B., Kale, P.N., Ajri, D.S. and Lawande, K.E. 1988. Chemical control of fruit borer of okra. J. Maharashtra Agric. Univ., 13(1): 115-117.

PDVR, 1994. Resistance breeding in okra. Project Directorate of Vegetable Research - Annual Report. Varanasi, Pp. 39-40.

Prabu, T. 2009. Screening Wild and Cultivated Okra Species for Resistance to important Pests. Ind. J. Plant Prot., 37(1\&2): 87-91.

Pun, K.B, Doraiswamy, S. and Balasubramanian, G. 2005. Prediction of whitefly population and okra yellow vein mosaic virus disease incidence in okra. Ind. J. of Virology, 16: $19-23$.

Rai, S. and Satpathy, S. 1998. Recent advances in screening for insect resistance in vegetables. Instructional manual of summer school on "Advanced technologies in improvement of vegetable crops including cole crops", May 4-24, AIRI, New Delhi, India, pp. 97-74.

Ramarathinam, S. 1998. Neem formulation best suited for IPM. Pestology, 22(6): 63-71.

Sharma, B.N. and Singh, S. 2010. Biophysical and biochemical factors of resistance in okra against shoot and fruit borer. Ind. J. Ent., 72: 212-216.

Singh, K.N. 1996. Potential of neem for pest management of stored grain insect in development. Pestology, 20(3): 29-33.

Sumathi, E. 1999. Studies on major pest bhendi (Abelmoschus esculentus (L.) Moench) and development of integrated pest management. Dissertation of M.Sc. (Ag.), Tamil Nadu Agricultural University, Coimbatore, pp. 1-134.

Verma, S. 1989. Efficacy and persistence of some insecticides against jassid infesting okra, (Abelmoschus esculentus). Plant Prot. Bull., 41(1\&2): 1-3. 